\title{
Histological reclassification of 101 intraoral salivary gland tumours (new WHO classification)
}

\author{
J E van der Wal, G B Snow, I van der Waal
}

\begin{abstract}
The epithelial salivary gland tumours have for many years been categorised according to the 1972 World Health Organisation (WHO) classification. In 1990 a proposed revision of this classification was elaborated. In this study 101 intraoral salivary gland tumours were reclassified accordingly. In 29 of the cases the original histological diagnosis was changed, which in most cases, occurred in the benign or malignant tumour groups. In seven cases the diagnosis was changed from benign to malignant or vice versa.
\end{abstract}

The results of this study show that the histological classification of intraoral salivary gland tumours remains difficult, even when applying the new WHO classification.

Salivary gland tumours account for about 3\% of all head and neck neoplasms, most being of epithelial origin. ${ }^{1}$ About $90 \%$ of these neoplasms are located in the major salivary glands, the other $10 \%$ in the minor salivary glands. ${ }^{23}$ Epithelial salivary gland tumours consist of a great variety of histological types and have until recently been classified according to the 1972 World Health Organisation (WHO) classification. ${ }^{4}$ Since 1972 several new tumour entities have been reported. Therefore, a proposed revision of the WHO Histological Classification of Salivary Gland Tumors was elaborated. ${ }^{5}$ In this study 101 intraoral salivary gland tumors were reclassified according to this new classification.

\section{Methods}

Department of Oral and Maxillofacial Surgery and Oral Pathology

J E van der Wal

I van der Waal

\section{Department of}

Otolaryngology/Head

and Neck Surgery,

Free University

Hospital, Amsterdam,

the Netherlands

G B Snow

Correspondence to:

Professor I van der Waal

Department of Oral \&

Maxillofacial Surgery, Free

University Hospital, De

Boelelaan 1117, $1081 \mathrm{HV}$

Amsterdam, the Netherlands

Accepted for publication

5 February 1992
Between January 1970 and January 1988101 patients with a tumour of the intraoral salivary glands were registered at the Free University Hospital in Amsterdam. There were 50 male and 51 female patients with a mean age of 53.6 1972 WHO classification) ${ }^{4}$ (range 17-86) years and 50.0 (range 16-82) years, respectively. The distribution of the 101 tumours according to the localisation and original histological diagnosis (WHO, 1972) are shown in table 1. Most patients had a malignant tumour $(57 \%)$ on first diagnosis, which included mucoepidermoid tumour and acinic cell tumour. Pleomorphic adenoma was the most common histological type.

Most of the 101 patients were initially treated by surgery. Eight patients were not treated surgically due to their age, general condition, or size and extension of the tumour. In cases of questionable or positive surgical margins postoperative radiotherapy was given.

All patients with a salivary gland tumour are routinely seen for follow up for at least 10 years. The mean follow up period was 6.5 (range 2-18) years.

Slides stained with hematoxylin and eosin were available for reclassification in every case. No special stains were used. The tumours were reclassified according to the Tentative Histological Classification of Salivary Gland Tumors. ${ }^{5}$

\section{Results}

The outcome of the reclassification is shown in table 2 . In 29 cases (29\%) the original histological diagnosis was changed.

In 15 of these cases it concerned a subclassification within a histological tumour type either benign or malignant:

1 the subdivision of adenocarcinomas in polymorphous low grade adenocarcinoma, papillary cystadenocarcinoma and adenocarcinoma, not otherwise specified;

2 the subdivision of monomorphic adenomas in canalicular adenoma and basal cell adenoma;

3 the reclassification of two monomorphic adenomas and two pleomorphic adenomas as myoepitheliomas.

In seven cases there was a change of diag-

Table 1 Distribution of 101 intraoral salivary gland tumours according to site and histological type (original diagnosis,

\begin{tabular}{|c|c|c|c|c|c|c|c|c|c|c|}
\hline & Palate & $\begin{array}{l}\text { Upper } \\
\text { lip }\end{array}$ & $\begin{array}{l}\text { Lower } \\
\text { lip }\end{array}$ & Cheek & $\begin{array}{l}\text { Floor } \\
\text { of the } \\
\text { mouth }\end{array}$ & $\begin{array}{l}\text { Retromolar } \\
\text { area }\end{array}$ & $\begin{array}{l}\text { Upper } \\
\text { alveolar } \\
\text { ridge }\end{array}$ & Mandible & Tongue & Total \\
\hline $\begin{array}{l}\text { Pleomorphic adenoma } \\
\text { Monomorphic adenoma } \\
\text { Mucoepidermoid tumour } \\
\text { Acinic cell tumour } \\
\text { Adenoid cystic carcinoma } \\
\text { Adenocarcinoma } \\
\text { Carcinoma in pleomorphic adenoma }\end{array}$ & $\begin{array}{r}27 \\
3 \\
8 \\
2 \\
15 \\
5 \\
1\end{array}$ & $\begin{array}{r}4 \\
4 \\
- \\
2 \\
1 \\
-\end{array}$ & $\begin{array}{l}\frac{1}{1} \\
\frac{1}{-} \\
-\end{array}$ & $\begin{array}{l}4 \\
1 \\
\frac{2}{1} \\
\frac{1}{-}\end{array}$ & $\frac{-}{1}$ & $\begin{array}{l}- \\
1 \\
1 \\
1 \\
-\end{array}$ & $\begin{array}{l}\frac{-}{1} \\
\frac{1}{3} \\
2 \\
1\end{array}$ & $\begin{array}{l}\overline{-} \\
\overline{1} \\
\frac{1}{-}\end{array}$ & $\begin{array}{l}\overline{-} \\
\frac{1}{-} \\
\overline{-}\end{array}$ & $\begin{array}{r}36 \\
8 \\
15 \\
3 \\
27 \\
9 \\
3\end{array}$ \\
\hline Total & 61 & 11 & 2 & 8 & 7 & 3 & 7 & 1 & 1 & 101 \\
\hline
\end{tabular}


Table 2 Distribution of 101 histological types according to 1972 WHO classification and tentative WHO classification (1990) for salivary gland tumours

\begin{tabular}{|c|c|c|c|}
\hline WHO, $1972^{4}$ & $n=$ & WHO, $1990^{5}$ & $n=$ \\
\hline $\begin{array}{l}\text { Pleomorphic adenoma } \\
\text { Monomorphic adenoma }\end{array}$ & $\begin{array}{r}36 \\
8\end{array}$ & $\begin{array}{l}\text { Pleomorphic adenoma } \\
\text { Myoepithelioma } \\
\text { Basal cell adenoma } \\
\text { Canalicular adenoma } \\
\text { Intraductal papilloma }\end{array}$ & $\begin{array}{r}33 \\
4 \\
1 \\
3 \\
1\end{array}$ \\
\hline Mucoepidermoid tumour & 15 & $\begin{array}{l}\text { Mucoepidermoid carcinoma, } \\
\text { low grade } \\
\text { high grade }\end{array}$ & $\begin{array}{r}11 \\
2\end{array}$ \\
\hline Acinic cell tumour & 3 & Acinic cell carcinoma & 4 \\
\hline Adenoid cystic carcinoma & 27 & $\begin{array}{l}\text { Adenoid cystic carcinoma } \\
\text { glandular/tubular } \\
\text { solid }\end{array}$ & $\begin{array}{r}22 \\
5\end{array}$ \\
\hline Adenocarcinoma & 9 & $\begin{array}{l}\text { Polymorphous low grade } \\
\text { adenocarcinoma } \\
\text { Papillary cystadenocarcinoma } \\
\text { Adenocarcinoma, NOS }\end{array}$ & $\begin{array}{l}8 \\
1 \\
3\end{array}$ \\
\hline Carcinoma in pleomorphic adenoma & 3 & $\begin{array}{l}\text { Carcinoma in pleomorphic adenoma } \\
\text { invasive } \\
\text { non-invasive } \\
\text { Salivary duct cyst }\end{array}$ & $\begin{array}{l}1 \\
1 \\
1\end{array}$ \\
\hline
\end{tabular}

Table 3 Seven cases that changed diagnosis from benign to malignant, or vice versa, in reclassification

\begin{tabular}{ll}
\hline Original diagnosis & Reclassification \\
\hline Pleomorphic adenoma & Polymorphous low grade adenocarcinoma \\
Pleomorphic adenoma & Polymorphous low grade adenocarcinoma \\
Monomorphic adenoma & Mucoepidermoid carcinoma \\
Monomorphic adenoma & Adenoid cystic carcinoma, glandular type \\
Mucoepidermoid tumour & Pleomorphic adenoma \\
Mucoepidermoid tumour & Salivary duct cyst \\
Adenoid cystic carcinoma & Intraductal papilloma \\
\hline
\end{tabular}

nosis within the malignant tumour group-for example, from adenocarcinoma to adenoid cystic carcinoma, or carcinoma in pleomorphic adenoma. Of the remaining seven cases, four benign diagnoses were changed into a malignant diagnosis and three malignant diagnoses were changed into a benign diagnosis (table 3).

\section{Discussion}

The distribution of the histological types and tumour sites in this study are somewhat similar to those of other studies on intraoral salivary gland tumours, the palate being the most common location and the pleomorphic adenoma being the most common histological type. ${ }^{6}$
As shown by the results of this study the histological classification of intraoral salivary gland tumours remains difficult, even when applying the new WHO classification. ${ }^{7}$ In $29 \%$ of cases the original histological diagnosis was changed. In most of these cases the change of diagnosis occurred either within the benign or within the malignant tumour group. In adenocarcinomas more detailed histological typing may lead to a better prediction of the prognosis. This seems especially true with regard to the polymorphous low grade adenocarcinoma. However, the clinical relevance of the new subtyping of adenomas seems somewhat questionable, although it has been claimed that the myoepithelioma is a potentially more aggressive neoplasm. ${ }^{5}$

In seven cases there was a change in diagnosis from benign to malignant, or vice versa. Benign tumours of the minor salivary glands tend to be non-encapsulated which can make the differentiation between adenomas and carcinomas difficult - for example, the differential diagnosis between pleomorphic adenoma and polymorphous low grade adenocarcinoma.

The follow up data of this study did not corroborate the accuracy of the reclassified diagnoses.

1 Eveson JW, Cawson RA. Salivary gland tumours: a review of 2410 cases with particular reference to histologic types, site, age and sex distribution. f Oral Pathol 1985;146:51-8.

2 Spiro RH. Salivary neoplasms: overview of a 35-year experience with 2807 patients. Head Neck Surg 1986;8:177-84.

3 Waldron CA, El-Mofty SK, Gnepp DR. Tumors of the intraoral minor salivary glands: a demographic and histologic study of 426 cases. Oral Surg Oral Med Oral Pathol 1988;66:323-33.

4 Thackray AC, Sobin LH. Histological typing of salivary gland tumors. WHO international histological classification of tumours, No 7. Geneva: World Health Organization, of tumour.

5 Seifert G, Brocheriou C, Cardesa A, Eveson JW. WHO international histological classification of tumours. Tenta-
tive histological classification of salivary gland tumours. tive histological classification of

6 Chau MNY, Radden BG. Intraoral salivary gland neoplasms: a retrospective study of 98 cases. $\mathcal{f}$ Oral Pathol 1986;15:339-42.

7 Tischendorf L, Herrmann PK, Luttermann Th. Konsequenzen aus Studien zur Reklassifizierung von Geschwulsten der Kopfspeicheldrüsen. Dtsch Z Mund Kiefer Gesichts Chir 1991;15:35-7. 